\title{
Wilderness medicine
}

\author{
Douglas G. Sward ${ }^{1}$, Brad L. Bennett ${ }^{2}$ \\ ${ }^{1}$ Department of Emergency Medicine, University of Maryland School of Medicine, Hyperbaric Medicine, Shock Trauma \\ Center, Baltimore, Maryland, USA \\ ${ }^{2}$ Military \& Emergency Medicine Department, F. Edward Hébert School of Medicine, Uniformed Services University of the \\ Health Sciences, Bethesda, Maryland, USA
}

Corresponding Author: Douglas G. Sward,Email: dsward@umm.edu

BACKGROUND: Human activity in wilderness areas has increased globally in recent decades, leading to increased risk of injury and illness. Wilderness medicine has developed in response to both need and interest.

METHODS: The field of wilderness medicine encompasses many areas of interest. Some focus on special circumstances (such as avalanches) while others have a broader scope (such as trauma care). Several core areas of key interest within wilderness medicine are discussed in this study.

RESULTS: Wilderness medicine is characterized by remote and improvised care of patients with routine or exotic illnesses or trauma, limited resources and manpower, and delayed evacuation to definitive care. Wilderness medicine is developing rapidly and draws from the breadth of medical and surgical subspecialties as well as the technical fields of mountaineering, climbing, and diving. Research, epidemiology, and evidence-based guidelines are evolving. A hallmark of this field is injury prevention and risk mitigation. The range of topics encompasses high-altitude cerebral edema, decompression sickness, snake envenomation, lightning injury, extremity trauma, and gastroenteritis. Several professional societies, academic fellowships, and training organizations offer education and resources for laypeople and health care professionals.

CONCLUSIONS: The future of wilderness medicine is unfolding on multiple fronts: education, research, training, technology, communications, and environment. Although wilderness medicine research is technically difficult to perform, it is essential to deepening our understanding of the contribution of specific techniques in achieving improvements in clinical outcomes.

KEY WORDS: Wilderness medicine; High-altitude sickness; Dive medicine; Envenomation; Trauma; Hyperthermia; Hypothermia; Frostbite; Avalanche; Combat injuries; Search and rescue; Travel medicine; Disaster medicine

\section{INTRODUCTION}

Wilderness medicine is a multifaceted field of medical practice with a long history. ${ }^{[1]}$ Its definition must consider concepts of distance and time from typical hospital care, the activity in which an injured or ill person was engaged, the possibility of prolonged environmental exposure, a scarcity of resources, and the risks faced by rescuers and health care providers. A flexible approach to planning, patient assessment, and evacuation is mandatory. ${ }^{[2,3]}$ Howard D. Backer, MD, a pastpresident of the Wilderness Medical Society, eloquently described wilderness medicine by its remoteness, physiology, need for improvisation, and dependence on clinical examination and judgment. ${ }^{[4]}$ In stark contrast, "street" medicine benefits from an abundance of rescue personnel, technologic capability, and rapid ground and air transportation to facilities that can provide definitive care.

Ongoing basic research and epidemiology continue 
to define and refine wilderness medicine, reporting morbidity and mortality rates from diverse populations and regions. Data from U.S. National Parks indicate that the most common injuries treated by wilderness medicine specialists are soft-tissue lesions, sprains, strains, and lower-extremity fractures. ${ }^{[5-7]}$

\section{Early development}

In 1983, the Wilderness Medical Society (WMS) was founded by three physicians: Drs. Greer, Auerbach, and Kizer, from northern California. This non-profit organization is based in Salt Lake City, Utah, USA. Its objectives are to advance wilderness medicine health care, education, and research. ${ }^{[8]}$ The society launched the Journal of Wilderness Medicine in 1987 as a peer-reviewed and indexed publication. As the journal matured, its name was changed to Wilderness and Environmental Medicine. It is published quarterly and contains articles on bench and clinical research as well as editorials. Other journals that address topics in wilderness medicine include High Altitude Medicine and Biology; Military Medicine; Journal of Special Operations Medicine; Aviation Space and Environmental Medicine; Undersea and Hyperbaric Medicine; Diving and Hyperbaric Medicine; Journal of Applied Physiology; Medicine \& Science in Sports \& Exercise; and the Journal of Venom Research. An additional resource is the quarterly newsletter Wilderness Medicine Magazine (www.wildernessmedicinemagazine.com), which started as a pamphlet and has developed into an online, interactive, hyperlinked publication.

Basic care recommendations were first published in WMS Practice Guidelines for Wilderness Emergency Care, edited by William Forgey, MD; the fifth edition of this book was published in 2006. ${ }^{[9]}$ These practice guidelines are updated by subject matter experts, ranked by class of evidence, and published individually as the Wilderness Medical Society Practice Guidelines. They are indexed and published in the journal Wilderness and Environmental Medicine.

Paul Auerbach, MD, edits the primary textbook on the topic, Wilderness Medicine. ${ }^{[10]}$ The sixth edition, published in 2012, contains 114 chapters.

\section{Areas of interest}

The field of wilderness medicine encompasses many areas of interest. Some focus on special circumstances (such as avalanches) while others have a broader scope (such as trauma care). Several core areas of key interest within wilderness medicine are discussed in this section.

\section{High altitude}

High-altitude travel is common and increasing. From ski resorts to mountaineering, the incidence of acute mountain sickness (AMS) is high, estimated to affect $25 \%$ of people who ascend to even moderate altitudes. ${ }^{[1]}$ High-altitude pulmonary edema (HAPE) and high-altitude cerebral edema (HACE) are more serious life-threatening conditions and, thankfully, are less common. ${ }^{[12-15]}$ The primary treatment for these conditions involves descent and administration of oxygen. Pharmacologic management usually begins with acetazolamide and glucocorticoid steroids. ${ }^{[16,17]}$

\section{Dive medicine}

Diving for recreation and technical purposes is increasingly popular worldwide. Dive-specific injuries include decompression illness and barotrauma. The incidence of decompression illness appears to be stable across recreational, professional, and scientific venues $(0.003 \%-0.01 \%)$. Scientific diving has the lowest rate of injury. ${ }^{[18,19]}$ Decompression illness is triggered by decompression stress and subsequent nitrogen bubble formation, possibly pro-inflammatory microparticle formation. ${ }^{[20]}$ Interestingly, inner-ear decompression illness has been diagnosed more frequently in recent years. ${ }^{[21,22]}$ Treatment includes recompression in a hyperbaric chamber; portable chambers for use in remote areas are being developed. ${ }^{[23]}$ A number of descriptions of in-water recompression have been published. ${ }^{[24-27]}$

\section{Envenomation}

The toxicology and pathology of snake bites, arthropod stings, and marine envenomations vary widely, with significant differences in management based on location. This variation is related to local fauna as well as the availability (or lack) of anti-venoms. ${ }^{[28]}$ Victims' reactions to envenomation are often self-limiting, but systemic reactions leading to coagulopathy or respiratory arrest induced by neurotoxins are certainly possible. Some envenomations, such as from Cubozoa jellyfish, can lead to massive adrenergic surge and cardiovascular collapse.$^{[29-36]}$

\section{Trauma}

Trauma is a common cause of wilderness morbidity. A leading cause of trauma mortality is head injury after a fall from height during hiking, rock climbing, mountain biking, and snow-related activities. Although most traumatic injuries are "minor" and involve the lower extremities, they often end outdoor activities and extended trips. In rare events, trauma involves multiple systems and becomes life-threatening. 
This category of wilderness medicine includes injuries sustained in motor vehicle crashes that occur during travel to and within remote areas. ${ }^{[6]}$ Retrospective surveys have shed light on the nature and frequency of traumatic injuries sustained while climbing. ${ }^{[37-46]}$

Advances in cervical spine management and immobilization, opiate-based pain control, and invasive procedures are being discussed. ${ }^{[47-51]}$ Advanced techniques such as shoulder reduction are being taught to lay providers. ${ }^{[52]}$ Even such specialized injuries as prolonged harness suspension are being considered. ${ }^{[53]}$

\section{Hyperthermia}

Heat exposure and heat stress can cause a spectrum of illness, ranging from benign heat cramps to lifethreatening heatstroke. ${ }^{[54]}$ Heatstroke is a severe, sometimes fatal, disease that is defined as elevated core temperature accompanied by neurologic dysfunction. Heatstroke is a complex process that involves cellular dysfunction, cardiac conduction dysfunction, release of pro-inflammatory cytokines, concomitant intravascular depletion, and subsequent circulatory collapse. ${ }^{[55]}$ The degree of dehydration varies. In contrast to classic heatstroke, exertional heatstroke can occur even in moderate temperatures, especially among endurance wilderness athletes. ${ }^{[56]}$

Removal from the heat stress and rapid whole body cooling are essential to mitigate encephalopathy, coagulopathy, and multi-organ failure. ${ }^{[57-59]}$ The optimal cooling technique is total body immersion in ice or cold water, but this intervention is usually not practical in wilderness settings. Under these circumstances, skin wetting and aggressive fanning can be used in an attempt to lower the patient's temperature. This technique might induce shivering, but there is no evidence suggesting that the concomitant heat production conflicts with the attempt to lower the core temperature. ${ }^{[60,61]}$

\section{Hypothermia}

Accidental hypothermia is a common concern in wilderness medicine both as a primary condition and as a complication of illness or trauma. The mortality rate increases when the core temperature falls below $95{ }^{\circ} \mathrm{F}$ $\left(35{ }^{\circ} \mathrm{C}\right)$ in association with trauma, resulting in acidosis, coagulopathy, and multiple organ dysfunction. ${ }^{[62,63]}$ Hypothermia occurs when cold stress is not matched by heat production. Interestingly, hypothermia can even occur in temperate climates. ${ }^{[64]}$

Multiple physiologic and behavioral mechanisms work together to maintain euthermia; however, they can fail when certain temperature thresholds are reached. "Paradoxic undressing" is thought to be caused by cutaneous vasodilation and alterations in cognition; "terminal burrowing" might be a primitive reflex. ${ }^{[65-67]}$

The basics of hypothermia resuscitation include prevention of further heat loss, rewarming, and support of physiologic processes ${ }^{[68,69]}$ Field research with healthy subjects and invasive monitoring has clarified the physiology of cooling and afterdrop. Improvised and commercial methods for preventing further body heat loss are being developed. ${ }^{[70-75]}$ Arteriovenous anastomoses rewarming with or without negativepressure devices could offer a technique to rapidly rewarm severely hypothermic patients in the field. ${ }^{[76,77]}$

Resuscitation protocols for hypothermia and cardiac arrest have long engendered controversy, because of the resources that are required and the dismal recovery statistics. In some cases, prolonged resuscitation will be successful in achieving a positive neurologic outcome. But, in remote settings, the required resources are usually not available. ${ }^{[9,78]}$ Nonetheless, the state of Alaska has had progressive emergency medical services (EMS) protocols in place for a long time to guide the pre-hospital response to victims hypothermia combined with cardiac arrest in remote settings. ${ }^{[79,80]}$

\section{Frostbite}

Frostbite is a complex process in which tissue cooling causes vasoconstriction, ischemia, and intracellular and extracellular ice crystal formation, leading to cell lysis and cell death. Reperfusion-ischemia injury is possible, and repeated thawing and refreezing is particularly damaging. Recent practice guidelines from the Wilderness Medical Society discuss the dichotomy between intentional field rewarming of a frozen body part, with maintenance of thawed tissue, and keeping the tissue frozen when the risk of re-freezing is significant. ${ }^{[81]}$

Basic field care includes administration of antiprostaglandins, pain control, and placement of protective dressings in addition to treating concomitant hypothermia and injuries. Debridement of nonhemorrhagic blisters might be beneficial, but evidence is lacking. In medical facilities, advanced care with tissue plasminogen activator or prostaglandins/PG analogues has been documented. In the past, a "wait-and-see" approach was used to determine demarcation of the frozen area; now, tissue viability can be determined rapidly with advanced imaging such as magnetic resonance angiography or 
bone scintigraphy. ${ }^{[81]}$

\section{Avalanche}

Avalanches most commonly occur in mountainous terrain with $35 \%$ slope when a buried layer fails and releases an overlying slab of snow. Victims caught in an avalanche are subjected to tremendous traumatic forces and are at risk of suffocation and, eventually, hypothermia. The severity of avalanche injury is generally based on several factors: depth of burial, length of burial, airway obstruction, and concurrent trauma. ${ }^{[82-84]}$ Avalanche rescue and resuscitation have been advanced by an improved understanding of snow burial physiology, including cooling, afterdrop, and the role of exhaled carbon dioxide. ${ }^{[85,86]}$ Technologic advances designed to mitigate the risk of avalanche-associated injury and death include exhaled air diversion devices, flotation devices, and transceivers. ${ }^{[87]}$ The science of avalanche forecasting has improved; detailed reports are available online. ${ }^{[88]}$ Despite these advances, North American avalanche fatalities continue their upward trend. ${ }^{[89]}$ Morbidity and mortality rates associated with non-avalanche snow burial (tree well and deep snow immersion asphyxia) are also being documented. ${ }^{[90]}$

\section{Military medicine}

Tactical/battlefield medicine has advanced dramatically in the past decade, including the development of tactical combat casualty care guidelines and training. Significant advances have been achieved in hemorrhage control with tourniquets and hemostatic agents, surgical cricothyroidotomy, intraosseous access, needle decompression, pain management, prophylactic antibiotics, and low-volume field resuscitation. These advances are now crossing over to civilian EMS systems, tactical units, and wilderness medicine. ${ }^{[91-98]}$

\section{Epidemiology}

Wilderness medicine epidemiology is a rapidly growing field that describes the incidence of morbidity and mortality in the wilderness. Detailed information is still being collected, but general trends can be described. The most common injuries are soft-tissue lesions (e.g., blisters), sprains, strains, and fractures. The most common causes of death are head trauma, cardiac arrest (males $>55$ years old), drowning, hypothermia, hyperthermia, and suicide..$^{[5,6,10,99-106]}$ These data are important for general educational programs, risk mitigation, trip planning, and medical kit stocking. ${ }^{[7]}$

\section{Search and rescue}

Search and rescue operations are conducted under many organizational structures, typically citizen volunteer groups, law enforcement agencies, or, in many localities, a blend of the two. ${ }^{[107]}$ Participants' medical training ranges from basic first aid to wilderness first aid, wilderness first responder, wilderness emergency medicine technician, paramedic, mid-level provider, as well as physician. Search and rescue missions are often used for missing children, recreationalists, and individuals with developmental delay, autism, Alzheimer's disease, or dementia. ${ }^{[99-101,108-112]}$ Search management has evolved to the point of using statistical models of subjects' behavior along with computer analysis and mapping. ${ }^{[113,114]}$ Helicopters facilitate rapid identification and extrication when they are deployed under appropriate circumstances. ${ }^{[115-119]}$

\section{Travel medicine}

Travel medicine involves the epidemiology of travelers' diseases, education, and vaccination. ${ }^{[120]}$ This specialty has become especially important in this era of easy long-distance travel. ${ }^{[121]} \mathrm{A}$ particularly important disease in travel medicine is malaria, which carries significant morbidity and mortality rates, especially among children. ${ }^{[122-124]}$ Geosentinel monitoring is used to detect disease propagation and assist with management. ${ }^{[125,126]}$

\section{Disaster medicine}

Disaster medicine and wilderness medicine have significant overlap. Both are practiced under sudden, unexpected, difficult, and austere conditions and have an inherent delay in emergency response and evacuation. Disaster conditions can be created in urban, suburban, and rural locations and are all associated with delays in emergency response, extraction, and evacuation to medical resources. Diseases that are typical in wilderness or remote settings can emerge in the aftermath of disasters. Although dramatic scenarios such as crush injuries and amputations grab news media attention, the basics of hygiene and water sanitation are just as critical in disaster management as is the deployment of trained response personnel into devastated areas. ${ }^{[127-129]}$

\section{Ultrasound}

Small, portable ultrasound machines are being used as an extension of the physical examination of patients with a number of clinical conditions: trauma (Focused Assessment with Sonography in Trauma [FAST] and pneumothorax examination), HAPE (pulmonary 
examination), HACE (determination of the diameter of the optic nerve sheath), and obstetric emergencies (determination of the age of the fetus). ${ }^{[130,131]}$ Increasing use of this technology is being reported by the US military, particularly by remote special forces medics in Afghanistan and at small remote receiving centers. ${ }^{[132,133]}$ Disaster medicine has used ultrasound in the field and in hospitals when other resources are overwhelmed or unavailable. ${ }^{[134-138]}$ These situations often employ ultrasound for the focused scans delineated in ACEP's Emergency Ultrasound Guidelines. ${ }^{[139]}$ The use of ultrasound in conjunction with telemedicine is intriguing. Real-time ultrasound images have even been transmitted from the International Space Station. ${ }^{[140,141]}$

\section{WMS practice guidelines}

Formal recommendations for clinical care and decision-making were lacking until 1979, when Forgey published Wilderness Medicine. ${ }^{[142]}$ Six editions have been published, the latest in 2006. ${ }^{[143]}$

Over the past several years, the evidence-based Wilderness Medical Society Practice Guidelines have been developed and published in several areas of wilderness medicine. The topics addressed in these guidelines include: high-altitude illness ${ }^{[16]}$ frostbite ${ }^{[81]}$ lightning, ${ }^{[144]}$ eye injuries, ${ }^{[145]}$ epinephrine, ${ }^{[146]}$ use of extrication devices in crevasse rescue, ${ }^{[147]}$ exercise-associated hyponatremia, ${ }^{[148]}$ spine trauma management, ${ }^{[51]}$ heat-related illness, ${ }^{[149]}$ anesthesia and pain management (in press), wound management (pending), hypothermia (pending), drowning and immersion injuries (pending). They are based on case series and expert consensus, because, for many topics, research studies using randomized controls have not yet been conducted. The guidelines were developed in accordance with the templates suggested by the American College of Chest Physicians. ${ }^{[149]}$

\section{Professional organizations}

The Wilderness Medical Society (WMS) is the primary professional organization representing wilderness medicine physicians and other health care providers. It sponsors a variety of meetings in North America: an annual summer meeting, an annual winter meeting, and a fall specialty meeting (organized around themes such as travel medicine, desert medicine, or environmental health). The WMS has developed a series of online video recordings from past conferences for continuing medical education (CME). The World Congress in Wilderness Medicine has met every 10 years since 1991, providing a forum for the exchange of current ideas and concepts related to wilderness medicine. The International Society for Mountain Medicine sponsors the International Hypoxia Symposium and the Congress on High Altitude Medicine and Physiology. The Undersea and Hyperbaric Medical Society, the Divers Alert Network, and the South Pacific Undersea Medicine Society focus on dive medicine.

Several other professional societies play important roles in wilderness medicine. The International Society of Travel Medicine (www.istm.org), founded in 1988, focuses on travel-related disease, including immunization recommendations. ISTM is involved in global monitoring of infectious diseases. Together with the Centers for Disease Control and Prevention (CDC), ISTM manages Geosentinel, a global surveillance network for infectious diseases that provides nearly realtime data for analysis of evolving disease patterns. The International Commission for Alpine Rescue (www.ikarcisa.org), founded in 1948 and based in Switzerland, represents European mountain rescue groups. ICAR publishes recommendations on both medical and technical issues for a variety of issues facing mountain rescue teams. The International Society for Mountain Medicine (http://ismmed.org), founded in 1985 and also based in Switzerland, publishes the journal High Altitude Medicine and Biology.

\section{Fellowships}

The purpose of wilderness medicine fellowships is to develop academic leaders in the specialty. Multiple postgraduate fellowships are based in emergency medicine and family medicine graduate medical education programs. Generally, they have a research component, a teaching component, and a field component. A typical pattern is 1 year of training, with part-time clinical attending duties and part-time wilderness medicine training. The program at the University of California, Fresno, has an optional 1-year extension to obtain a master's degree in public health. The program at George Washington University also offers the opportunity to complete a master of science or a master of public health degree. The original and best known wilderness medicine fellowship is based at Stanford University in Palo Alto, California. The Society for Academic Emergency Medicine lists eight other wilderness medicine fellowships associated with emergency medicine residency programs. They are located at Baystate Medical Center; the University of California, San Francisco-Fresno; the Medical College of 
Georgia; the University of Utah; Massachusetts General Hospital; the University of Colorado; the State University of New York; and Loma Linda University. Additionally, the Madigan Army Medical Center hosts an Austere and Wilderness Medicine fellowship for military physicians.

Several family medicine programs also host wilderness medicine fellowships: the Montana Family Medicine Program (www.riverstonehealth.org), the family medicine residency of Idaho (www.fmridaho.org), and Saint Vincent Wilderness Medicine Track (www. stvincenthealth.com).

\section{Academy of wilderness medicine}

Under the auspices of the Wilderness Medical Society, the Academy of Wilderness Medicine offers a fellowship that provides rigorous education through a 100 -hour core curriculum as well as requirements for service, teaching, research, and experience. As of June 2013, the Academy recognizes more than 260 fellows as well as more than 700 fellowship candidates.

\section{Master's degree}

The Wilderness Medical Society opened its master's degree program (http://wms.org/fawm/acad_information. asp) in 2009. This program offers advanced, post-fellow certification in the participant's chosen sub-discipline within the scope of wilderness medicine. The master's program is developed by the student and a mentor and must meet requirements in education, scholarly activity, and experimental activity. For example, a master's program in the subspecialty of dive medicine could focus on the clinical management of decompression illness. Most participants fulfill the requirements of their program within 2 to 5 years.

\section{Diploma in mountain medicine}

In collaboration with the University of Utah and the University of Colorado, the Wilderness Medical Society also awards diplomas in mountain medicine, certifying academic and advanced skills in mountain rescue techniques (http://wms.org/education/dimm.asp). Started in 1997, the diploma program is co-sponsored by the Union Internationale Des Associations D'Alpinisme, the International Committee for Alpine Rescue, and the International Society for Mountain Medicine. The program is open to physicians, nurses, and paramedics who work in or aspire to work in austere environments. The 100 hours of coursework blend didactic and practical education in wilderness medicine, technical rescue, and self-sufficiency in the backcountry. This skill set crosses a number of disciplines, including expedition medicine, search and rescue operations, mountain guiding, ski patrol, and mountain recreation. The program consists of four week-long sessions that should be completed within 2 or 3 years. Participants must pass written and skills examinations to complete the program.

\section{Student interest groups}

The Wilderness Medical Society supports student interest groups that sponsor lecture series, workshops, and outdoor trips in conjunction with their sponsoring medical schools and faculty advisors. The events are organized by medical students, often in their second year of training. As of July 2013, approximately 43 of these interest groups, most of them in the United States and Europe, were active and operational. In addition, a number of emergency medicine and family medicine training programs in the United States offer 1- to 4-week electives in wilderness medicine for medical students and residents (see below).

\section{Schools of wilderness medicine}

Training in wilderness medicine is decentralized. Several organizations (based primarily in North America) teach wilderness medicine courses and skills throughout the world:

- Stonehearth Open Learning Opportunities (SOLO), Conway, New Hampshire, USA

- National Outdoor Leadership School, Wilderness Medicine Institute, Lander, Wyoming, USA

- Wilderness Medical Associates International, Portland, Maine, USA; Haliburton, Ontario, Canada; Tsukubamirai, Ibaraki, Japan (runs courses in China regularly)

- National Ski Patrol, Lakewood, Colorado, USA (outdoor emergency care)

- Advanced Wilderness Life Support, University of Utah, Salt Lake City, Utah, USA

- Aerie Backcountry Medicine, Missoula, Montana, USA

Their programs include basic introductory courses for the general public and pre-hospital care providers, such as wilderness first aid (WFA), a 2-day course; advanced wilderness first aid (AWFA), a 4-day course; wilderness first responder (WFR), a 9-day course; and wilderness emergency medical technician (WEMT), a 4-week course. Wilderness medicine courses for advanced care providers are available as well, e.g., Advanced Wilderness Life Saving. 
Table 1. Grants offered by the Wilderness Medical Society in Support of Health Research in Wilderness Medicine (www.wms.org/research).

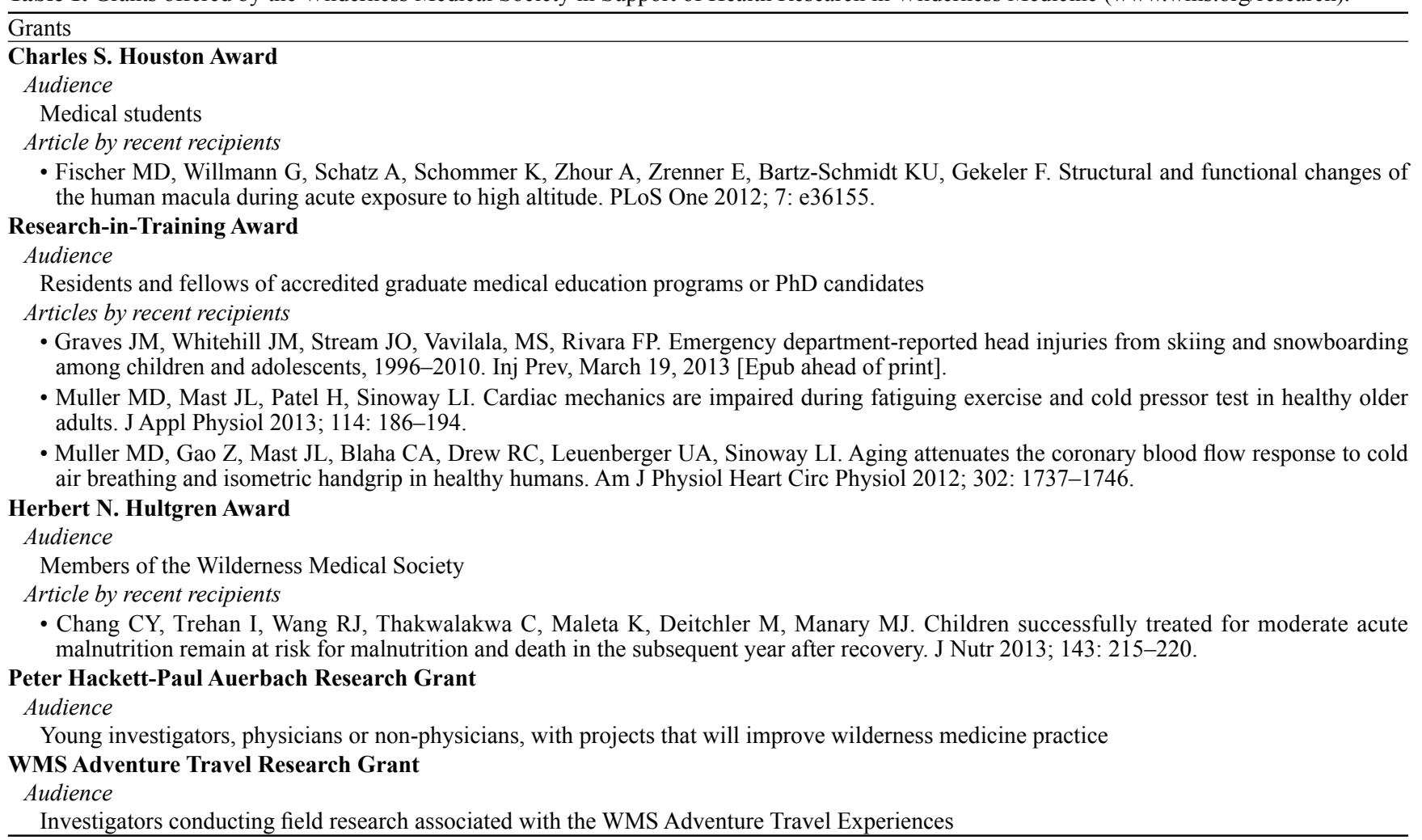

\section{Medical direction}

In the United States, street-based emergency medical services (EMS) systems are regulated by state agencies and the Department of Transportation at the federal level. Wilderness EMS does not have such a defined system of regulation. If present, medical oversight varies by jurisdiction. Only a few states have wilderness medicine integrated into their EMS protocols. In Pennsylvania and Maryland, two states with such integration, wilderness medicine practitioners are considered an extension of the pre-hospital system and have medical direction, follow wilderness specific protocols, and have quality assurance programs. In other states, wilderness medicine providers are not directly subservient to pre-hospital systems.

Many medical directors of EMS systems are unfamiliar with the practice of wilderness medicine, particularly its logistical limitations. To facilitate understanding and the integration of wilderness medicine into pre-hospital protocols, the Wilderness Medicine Society and the National Association of EMS Physicians (www.naemsp.org) have designed a Wilderness Medicine EMS Director Course, which is designed to support physicians who provide medical oversight to EMS systems with jurisdictions that cover wilderness environments. ${ }^{[150,151]}$ Topics include search and rescue teams, technical rescue teams, ski patrols, and disaster response teams.

\section{Wilderness research and grants}

The Wilderness Medical Society offers a number of grants intended to support health-related research projects in outdoor and wilderness activities. Examples are listed in Table 1.

\section{Future}

The future of wilderness medicine is unfolding on multiple fronts: education, research, training, technology, communications, and environment. A wide range of individuals is showing an interest in learning wilderness medicine skills. Although wilderness medicine research is technically difficult to perform, it is essential to deepening our understanding of the contribution of specific techniques in improving clinical outcomes.

\section{ACKNOWLEDGMENT}

We would like to thank to Linda J. Kesselring, MS, ELS, the technical editor/writer in the Department of Emergency Medicine at the University of Maryland School of Medicine, for copyediting the manuscript. 


\section{Funding: None.}

Ethical approval: Not needed.

Conflicts of interest: The authors declare that they have no conflicts of interest to report.

Contributors: Dr. Sward proposed the review and wrote the paper. He and Dr. Bennett both contributed to its content and to the development and revision of the text.

\section{REFERENCES}

1 Rodway GW. The foundations of wilderness medicine: some historical features. Wilderness Environ Med 2012; 23: 165-169.

2 Sholl JM, Curcia EP 3rd. An introduction to wilderness medicine. Emerg Med Clin North Am 2004; 22: 256-279.

3 Townes DA. Wilderness medicine. Prim Care 2002; 29: 1027 1048.

4 Backer H. What is wilderness medicine? Wilderness Environ Med 1995; 6: 3-10.

5 Baker J, Pat McKay M. Analysis of emergency medical services activations in Shenandoah National Park from 2003 to 2007. Prehosp Emerg Care 2010; 14: 182-186.

6 Forrester JD, Holstege CP. Injury and illness encountered in Shenandoah National Park. Wilderness Environ Med 2009; 20: 318-326.

7 Heggie TW, Heggie TM. Search and rescue trends and the emergency medical service workload in Utah's National Parks. Wilderness Environ Med 2008; 19: 164-171.

8 Barry J, Erb B. WMS Footprints: past, present, and future. Wilderness Medical Society. Available at www.wms.org/about/ history.asp. Accessed on October 8, 2013.

9 Forgey WW. Wilderness Medical Society Practice Guidelines for Wilderness Emergency Care, 5th ed. Guilford, Connecticut: FalconGuides; 2006.

10 Auerbach PS. Wilderness Medicine, 6th ed. Philadelphia: Elsevier; 2012: 2277.

11 Honigman B, Theis MK, Koziol-McLain J, Roach R, Yip R, Houston $\mathrm{C}$, et al. Acute mountain sickness in a general tourist population at moderate altitudes. Ann Intern Med 1993; 118: 587-592.

12 Bailey DM, Bartsch P, Knauth M, Baumgartner RW. Emerging concepts in acute mountain sickness and high-altitude cerebral edema: from the molecular to the morphological. Cell Mol Life Sci 2009; 66: 3583-3594.

13 Gallagher SA, Hackett PH. High-altitude illness. Emerg Med Clin North Am 2004; 22: 329-355.

14 Hackett PH, Roach RC. High-altitude illness. N Engl J Med 2001; 345: 107-114.

15 Imray C, Wright A, Subudhi A, Roach R. Acute mountain sickness: pathophysiology, prevention, and treatment. Prog Cardiovasc Dis 2010; 52: 467-484.

16 Luks AM, McIntosh SE, Grissom CK, Auerbach PS, Rodway GW, Schoene RB, et al. Wilderness Medical Society consensus guidelines for the prevention and treatment of acute altitude illness. Wilderness Environ Med 2010; 21: 146-155.

17 Maggiorini M. Prevention and treatment of high-altitude pulmonary edema. Prog Cardiovasc Dis 2010; 52: 500-506.

18 Ladd G, Stepan V, Stephens L. The Abacus Project: establishing the risk of recreational scuba death and decompression illness. South Pacific Underwater Med Soc J 2002; 32: 124-128.

19 Dardeau MR, Pollock NW, McDonald CM, Lang MA. The incidence of decompression illness in 10 years of scientific diving. Diving Hyperb Med 2012; 42: 195-200.

20 Thom SR, Milovanoa TN, Bogush M, Yang M, Bhopale VM, Pollock NW, et al. Bubbles, microparticles, and neutrophil activation: changes with exercise level and breathing gas during open-water SCUBA diving. J Appl Physiol 2013; 114: 13961405.

21 Klingmann C. Inner ear decompression sickness in compressedair diving. Undersea Hyperb Med 2012; 39: 589-594.

22 Nachum Z, Shupak A, Spitzer O, Sharoni Z, Doweck I, Gordon $\mathrm{CR}$. Inner ear decompression sickness in sport compressed-air diving. Laryngoscope 2001; 111: 851-856.

23 Vann RD, Butler FK, Mitchell SJ, Moon RE. Decompression illness. Lancet 2011; 377: 153-164.

24 Blatteau JE, Jean F, Pontier JM, Blanche E, Bompar JM, Meaudre E, et al. Decompression sickness accident management in remote areas: use of immediate in-water recompression therapy. Review and elaboration of a new protocol targeted for a mission at Clipperton atoll. Ann Fr Anesth Reanim 2006; 25: 874-883. [Article in French.]

25 Blatteau JE, Pontier JM. Effect of in-water recompression with oxygen to $6 \mathrm{msw}$ versus normobaric oxygen breathing on bubble formation in divers. Eur J Appl Physiol 2009; 106: 691-695.

26 Edmonds C. Underwater oxygen treatment of decompression sickness: a review. South Pacific Underwater Medicine Soc J 1995; $2: 17-26$.

27 Mitchell SJ, Doolette DJ, Wachholz CJ, Vann RD. Management of mild or marginal decompression illness in remote locations. Workshop Proceedings, Divers Alert Network, Durham, North Carolina, 2005.

28 Gutiérrez JM. Improving antivenom availability and accessibility: science, technology, and beyond. Toxicon 2012; 60: 676-687.

29 Currie BJ. Snakes, jellyfish and spiders. Adv Exp Med Biol 2008; 609: 43-52.

30 Currie BJ. Treatment of snakebite in Australia: the current evidence base and questions requiring collaborative multicentre prospective studies. Toxicon 2006; 48: 941-956.

31 Fernandez I, Valladolid G, Varon J, Sternbach G. Encounters with venomous sea-life. J Emerg Med 2011; 40: 103-112.

32 Gold BS, Barish RA, Dart RC. North American snake envenomation: diagnosis, treatment, and management. Emerg Med Clin North Am 2004; 22: 423-443.

33 Isbister GK. Antivenom efficacy or effectiveness: the Australian experience. Toxicology 2010; 268: 148-154.

34 Lavonas EJ, Ruha AM, Banner W, Bebarta V, Bernstein JN, Bush SP, et al. Unified treatment algorithm for the management of crotaline snakebite in the United States: results of an evidenceinformed consensus workshop. BMC Emerg Med 2011; 11: 2.

35 Norris RL. Managing arthropod bites and stings. Phys Sportsmed 1998; 26: 47-62.

36 Singletary EM, Rochman AS, Bodmer JC, Holstege CP. Envenomations. Med Clin North Am 2005; 89: 1195-1224.

37 Jones G, Asghar A, Llewellyn DJ. The epidemiology of rockclimbing injuries. Br J Sports Med 2008; 42: 773-778.

38 Lack DA, Sheets AL, Entin JM, Christenson DC. Rock climbing rescues: causes, injuries, and trends in Boulder County, Colorado. Wilderness Environ Med 2012; 23: 223-230.

39 Nelson NG, McKenzie LB. Rock climbing injuries treated in emergency departments in the U.S., 1990-2007. Am J Prev Med 2009; 37: 195-200. 
40 Schöffl V, Hochholzer T, Winkelmann HP, Roloff I, Strecker W. Pulley injuries in sport climbers. Handchir Mikrochir Plast Chir 2004;36: 224-230. [Article in German]

41 Schöffl V, Morrison A, Schwarz U, Schöffl I, Küpper T. Evaluation of injury and fatality risk in rock and ice climbing. Sports Med 2010; 40: 657-679.

42 Schöffl V, Morrison A, Schöffl I, Küpper T. The epidemiology of injury in mountaineering, rock and ice climbing. Med Sport Sci 2012; 58: 17-43.

43 Schöffl VR, Schöffl I. Injuries to the finger flexor pulley system in rock climbers: current concepts. J Hand Surg Am 2006; 31: 647-654.

44 Schöffl VR, Schöffl I. Finger pain in rock climbers: reaching the right differential diagnosis and therapy. J Sports Med Phys Fitness 2007; 47: 70-78.

45 Smith LO. Alpine climbing: injuries and illness. Phys Med Rehabil Clin N Am 2006; 17: 633-644.

46 Yamaguchi T, Ikuta Y. Climber's finger. Hand Surg 2007; 12: 59-65.

47 Ellerton J, Tomazin I, Brugger H, Paal P. Immobilization and splinting in mountain rescue: Official Recommendations of the International Commission for Mountain Emergency Medicine, ICAR MEDCOM, Intended for Mountain Rescue First Responders, Physicians, and Rescue Organizations. High Alt Med Biol 2009, 10: 337-342.

48 Kotwal RS, O'Connor KC, Johnson TR, Mosely DS, Meyer DE, Holcomb JB. A novel pain management strategy for combat casualty care. Ann Emerg Med 2004; 44: 121-127.

49 Wedmore IS, Johnson T, Czarnik J, Hendrix S. Pain management in the wilderness and operational setting. Emerg Med Clin North Am 2005; 23: 585-601.

50 Wharton DR, Bennett BL. Surgical cricothyrotomy in the wilderness: a case report. Wilderness Environ Med 2013; 24: 12-14.

51 Quinn R, Williams J, Bennett B, Stiller G, Islas A, McCord S. Wilderness Medical Society Practice Guidelines for Spine Immobilization in the Austere Environment. Wilderness Environ Med 2013; 24: 241-252.

52 Ditty J, Chisholm D, Davis SM, Estelle-Schmidt M. Safety and efficacy of attempts to reduce shoulder dislocations by nonmedical personnel in the wilderness setting. Wilderness Environ Med 2010; 21: 357-361.e2.

53 Mortimer RB. Risks and management of prolonged suspension in an alpine harness. Wilderness Environ Med 2011; 22: 77-86.

54 Epstein Y, Druyan A, Heled Y. Heat injury prevention-a military perspective. J Strength Cond Res 2012; 26: S82-S86.

55 Adams T, Stacey E, Stacey S, Martin D. Exertional heat stroke. Br J Hosp Med (Lond) 2012; 73: 72-78.

56 Brown DJ, Brugger H, Boyd J, Paal P. Accidental hypothermia. N Engl J Med 2102; 367: 1930-1938.

57 Casa DJ, Armstrong LE, Kenny GP, O'Connor FG, Huggins RA. Exertional heat stroke: new concepts regarding cause and care. Curr Sports Med Rep 2012; 11: 115-123.

58 Sithinamsuwan P, Piyavechviratana K, Kitthaweesin T, Chusri W, Orrawanhanothai P, Wongsa A, et al; Phramongkutklao Army Hospital Exertional Heatstroke Study Team. Exertional heatstroke: early recognition and outcome with aggressive combined cooling-a 12-year experience. Mil Med 2009; 174: 496-502.

59 Salathé C, Pellaton C, Vallotton L, Coronado M, Liaudet L. Exertional heatstroke. Rev Med Suisse 2012; 8: 2395-2399.
60 Casa DJ, McDermott BP, Lee EC, Yeargin SW, Armstrong LE, Maresh CM. Cold water immersion: the gold standard for exertional heatstroke treatment. Exerc Sport Sci Rev 2007; 35: 141-149.

61 Proulx CI, Ducharme MB, Kenny GP. Effect of water temperature on cooling efficiency during hyperthermia in humans. J Appl Physiol 2003; 94: 1317-1323.

62 Moffatt SE. Hypothermia in trauma. Emerg Med J 2012; 1: 1-8.

63 Søreide K. Clinical and translational aspects of hypothermia in major trauma patients: from pathophysiology to prevention, prognosis and potential preservation. Injury, January 23, 2013 [Epub ahead of print].

64 Lim C, Duflou J. Hypothermia fatalities in a temperate climate: Sydney, Australia. Pathology 2008; 40: 46-51.

65 Wedin B, Vanggaard L, Hirvonen J. "Paradoxical undressing" in fatal hypothermia. J Forensic Sci 1979; 24: 543-553.

66 Rothschild MA, Schneider V. "Terminal burrowing behavior"- a phenomenon of lethal hypothermia. Int J Legal Med 1995; 107: 250-256.

67 Brandström H, Eriksson A, Giesbrecht G, Angquist KA, Haney M. Fatal hypothermia: an analysis from a sub-arctic region. Int J Circumpolar Health 2012; 71: 1-7.

68 Geisbrecht GG. Prehospital treatment of hypothermia. Wilderness Environ Med 2001; 12: 24-31.

69 Geisbrecht GG. Emergency treatment of hypothermia. Emerg Med (Fremantle) 2001; 13: 9-13.

70 Grissom CK, Harmston CH, McAlpine JC, Radwin MI, Ellington B, Hirshberg EL, et al. Spontaneous endogenous core temperature rewarming after cooling due to snow burial. Wilderness Environ Med 2010; 21: 229-235.

71 Grissom CK, McAlpine JC, Harmston CH, Radwin MI, Giesbrecht GG, Scholand MB, et al. Hypercapnia effect on core cooling and shivering threshold during snow burial. Aviat Space Environ Med 2008; 79: 735-742.

72 Grissom CK, Radwin MI, Harmston CH, Hirshberg EL, Crowley TJ. Respiration during snow burial using an artificial air pocket. JAMA 2000; 283: 2266-2271.

73 Grissom CK, Radwin MI, Scholand MB, Harmston CH, Muetterties MC, Bywater TJ. Hypercapnia increases core temperature cooling rate during snow burial. J Appl Physiol 2004; 96: 1365-1370.

74 Hayward JS, Eckerson JD, Kemna D. Thermal and cardiovascular changes during three methods of resuscitation from mild hypothermia. Resuscitation 1984; 11: 21-33.

75 Radwin MI, Grissom CK, Scholand MB, Harmston CH. Normal oxygenation and ventilation during snow burial by the exclusion of exhaled carbon dioxide. Wilderness Environ Med 2001; 12: 256-262.

76 Soreide E, Grahn DA, Brock-Utne JG, Rosen L. A non-invasive means to effectively restore normothermia in cold-stressed individuals: a preliminary report. J Emerg Med 1999; 17: 725730.

77 Vanggaard L, Eyolfson D, Xu X, Weseen G, Geisbrecht G. Immersion of distal arms and legs in warm water (AVA rewarming) effectively rewarms mildly hypothermic humans. Aviat Space Environ Med 1999; 70: 1081-1088.

78 Southwick FS, Dalglish PH Jr. Recovery after prolonged asystolic cardiac arrest in profound hypothermia: a case report and literature review. JAMA 1980; 243: 1250-1253.

79 Samuelson T. Experience in standardized protocol in hypothermia, boon or bane? The Alaska experience. Arctic Med 
Res 1991; 50 (suppl 6): 28-31.

80 State of Alaska. Cold Injuries Guidelines. Juneau, Alaska: Department of Health and Social Services, 2005. Available at www.hypothermia.org/Hypothermia_Ed_pdf/Alaska-ColdInjuries.pdf. Accessed on October 14, 2013.

81 McIntosh SE, Hamonko M, Freer L, Grissom CK, Auerbach PS, Rodway GW, et al. Wilderness Medical Society practice guidelines for the prevention and treatment of frostbite. Wilderness Environ Med 2011; 22: 156-166.

82 Boyd J, Haegeli P, Abu-Laban RB, Shuster M, Butt JC. Patterns of death among avalanche fatalities: a 21-year review. CMAJ 2009; 180: 507-512.

83 Brugger H, Durrer B, Adler-Kastner L, Falk M, Tschirky F. Field management of avalanche victims. Resuscitation 2001; 51: 7-15.

84 McIntosh SE, Grissom CK, Olivares CR, Kim HS, Tremper B. Cause of death in avalanche fatalities. Wilderness Environ Med 2007; 18: 293-297.

85 Brugger H, Durrer B, Eisensohn F, Paal P, Strapazzon G, Winterberger E, et al. Resuscitation of avalanche victims: Evidence-based guidelines of the international commission for mountain emergency medicine (ICAR MEDCOM): intended for physicians and other advanced life support personnel. Resuscitation 2013; 84: 539-546.

86 Brugger H, Paal P, Boyd J. Prehospital resuscitation of the buried avalanche victim. High Alt Med Biol 2011; 12: 199-205.

87 Radwin MI, Grissom CK. Technological advances in avalanche survival. Wilderness Environ Med 2002; 13: 143-152.

88 Avalanche Stats. Utah Avalanche Center, Salt Lake City, Utah. Available at http://utahavalancecenter.org. Accessed on October 22, 2013.

89 Colorado Avalanche Information Center. Available at https:// avalanche.state.co.us. Accessed on October 22, 2013.

90 Van Tilburg C. Non-avalanche-related snow immersion deaths: tree well and deep snow immersion asphyxiation. Wilderness Environ Med 2010; 21: 257-261.

91 Bennett BL, Cailteux-Zevallos B, Kotora J. Cricothyroidotomy bottom-up training review: battlefield lessons learned. Mil Med 2011; 176: 1311-1319.

92 Blackbourne LH, Baer DG, Eastridge BJ, Kheirabadi B, Bagley S, Kragh JF Jr, et al. Military medical revolution: prehospital combat casualty care. J Trauma Acute Care Surg 2012; 73 (6 suppl 5): S372-S377.

93 Butler FK Jr, Blackbourne LH. Battlefield trauma care then and now: a decade of Tactical Combat Casualty Care. J Trauma Acute Care Surg 2012; 73 (6 suppl 5): S395-S402.

94 Dubick MA. Current concepts in fluid resuscitation for prehospital care of combat casualties. US Army Med Dep J 2011; Apr-Jun: 18-24.

95 Hessert MJ, Bennett BL. Optimizing emergent surgical cricothyrotomy for use in austere environments. Wilderness Environ Med 2013; 24: 53-66.

96 Walsh R, Heiner J, Kang C, Hile D, Deering S. Emergency physician evaluation of a novel surgical cricothyroidotomy tool in simulated combat and clinical environments. Mil Med 2013; 178: 29-33.

97 Pruitt BA Jr. The symbiosis of combat casualty care and civilian trauma care: 1914-2007. J Trauma 2008; 64 (2 suppl): S4-S8.

98 Bennett BL, Littlejohn L. Review of third-generation tropical hemostatic agents for Combat casualty care. Mil Med 2013 (in press).

99 Boore SM, Bock D. Ten years of search and rescue in Yosemite
National Park: examining the past for future prevention. Wilderness Environ Med 2013; 24: 2-7.

100 Ela GK. Epidemiology of wilderness search and rescue in New Hampshire, 1999-2001. Wilderness Environ Med 2004; 15: $11-17$.

101 Johnson J, Maertins M, Shalit M, Bierbaum TJ, Goldman DE, Lowe RA. Wilderness emergency medical services: the experiences at Sequoia and Kings Canyon National Parks. Am J Emerg Med 1991; 9: 211-216.

102 McIntosh SE, Leemon D, Visitacion J, Schimelpfenig T, Fosnocht D. Medical incidents and evacuations on wilderness expeditions. Wilderness Environ Med 2007; 18: 298-304.

103 Mort AJ, Godden DJ. UK mountain rescue casualties: 20022006. Emerg Med J 2010; 27: 309-312.

104 Mort A, Godden D. Injuries to individuals participating in mountain and wilderness sports: a review. Clin J Sport Med 2011; 21: 530-536.

105 Schindera ST, Triller J, Steinbach LS, Zimmermann H, Takala J, Anderson SE. Spectrum of injuries from glacial sports. Wilderness Environ Med 2005; 16: 33-37.

106 Wild FJ. Epidemiology of mountain search and rescue operations in Banff, Yoho, and Kootenay National Parks, 2003-06. Wilderness Environ Med 2008; 19: 245-251.

107 Brugger H, Elsensohn F, Syme D, Sumann G, Falk M. A survey of emergency medical services in mountain areas of Europe and North America: official recommendations of the International Commission for Mountain Emergency Medicine (ICAR Medcom). High Alt Med Biol 2005; 6: 226-237.

108 Heggie TW. Search and rescue in Alaska's national parks. Travel Med Infect Dis 2008; 6: 355-361.

109 Heggie TW, Amundson ME. Dead men walking: search and rescue in US National Parks. Wilderness Environ Med 2009; 20: 244-249.

110 Heggie TW, Heggie TM. Search and rescue trends associated with recreational travel in US national parks. J Travel Med 2009; 16: 23-27.

111 Hung EK, Townes DA. Search and rescue in Yosemite National Park: a 10-year review. Wilderness Environ Med 2007; 18: 111-116.

112 McIntosh SE, Brillhart A, Dow J, Grissom CK. Search and rescue activity on Denali, 1990 to 2008. Wilderness Environ Med 2010; 21: 103-108.

113 Koester RJ. Lost person behavior: a search and rescue guide on where to look - for land, air, water. Charlottesville, Virginia: dbS Productions LLC; 2008.

114 Adams AL, Schmidt TA, Newgard CD, Federiuk CS, Christie $\mathrm{M}$, Scorvo $\mathrm{S}$, et al. Search is a time-critical event: when search and rescue missions may become futile. Wilderness Environ Med 2007; 18: 95-101.

115 Carpenter J, Thomas F. A 10-year analysis of 214 HEMS backcountry hoist rescues. Air Med J 2013; 32: 98-101.

116 Grissom CK, Thomas F, James B. Medical helicopters in wilderness search and rescue operations. Air Med J 2006; 25: $18-25$.

117 Tomazin I, Ellerton J, Reisten O, Soteras I, Avbelj M; International Commission for Mountain Emergency Medicine. Medical standards for mountain rescue operations using helicopters: official consensus recommendations of the International Commission for Mountain Emergency Medicine (ICAR MEDCOM). High Alt Med Biol 2011; 12: 335-341.

118 Tomazin I, Kovacs T; International Commission for Mountain 
Emergency Medicine. Medical considerations in the use of helicopters in mountain rescue. High Alt Med Biol 2003; 4: 479-483.

119 van der Velde J, Linehan L, Cushack S. Helicopter winchmens' experiences with pain management in challenging environments. Ir Med J 2013; 106: 42-44.

120 Behrens RH, Carroll B. Travel trends and patterns of travelassociated morbidity. Infect Dis Clin North Am 2012; 26: 791-802.

121 Chen LH, Wilson ME, Davis X, Loutan L, Schwartz E, Keystone J, et al. GeoSentinel Surveillance Network. Illness in long-term travelers visiting GeoSentinel clinics. Emerg Infect Dis 2009; 15: 1773-1782.

122 Kheirabadi B. Evaluation of topical hemostatic agents for combat wound treatment. US Army Med Dep J 2011; Apr-Jun: 25-37.

123 Leder K, Black J, O'Brien D, Greenwood Z, Kain KC, Schwartz E, et al. Malaria in travelers: a review of the GeoSentinel surveillance network. Clin Infect Dis 2004; 39: 1104-1112.

124 Miller LH, Ackerman HC, Su XZ, Wellems TE. Malaria biology and pathogenesis: insights for new treatments. Nat Med 2013; 19: 156-167.

125 Marano C, Freedman DO. Global health surveillance and travelers' health. Curr Opin Infect Dis 2009; 22: 423-429.

126 Jensenius M, Han PV, Schlagenhauf P, Schwartz E, Parola P, Castelli $\mathrm{F}$, et al. Acute and potentially life-threatening tropical diseases in western travelers - a GeoSentinel multicenter study, 1996-2011. Am J Trop Med Hyg 2013; 88: 397-404.

127 Benjamin E, Bassily-Marcus AM, Babu E, Silver L, Martin ML. Principles and practice of disaster relief: lessons from Haiti. Mt Sinai J Med 2011; 78: 306-318.

128 Smith E, Wasiak J, Sen A, Archer F, Burkle FM Jr. Three decades of disasters: a review of disaster-specific literature from 1977-2009. Prehosp Disaster Med 2009; 24: 306-311.

129 Zhang L, Liu X, Li Y, Liu Y, Liu Z, Lin J, et al. Emergency medical rescue efforts after a major earthquake: lessons from the 2008 Wenchuan earthquake. Lancet 2012; 379: 853-861.

130 Nelson BP, Melnick ER, Li J. Portable ultrasound for remote environments, Part I: Feasibility of field deployment. J Emerg Med 2011; 40: 190-197.

131 Nelson BP, Melnick ER, Li J. Portable ultrasound for remote environments, Part III: current indications. J Emerg Med 2011; 40: 313-321.

132 Morgan AR, Vasios WN, Hubler DA, Benson PJ. Special operator level clinical ultrasound: an experience in application and training. J Spec Oper Med 2010; 10: 16-21.

133 Nations JA, Browning RF. Battlefield applications for handheld ultrasound. Ultrasound Q 2011; 27: 171-176.

134 Dan D, Mingsong L, Jie T, Xiaobo W, Zhong C, Yan L, et al. Ultrasonographic applications after mass casualty incident caused by Wenchuan earthquake. J Trauma 2010; 68: 14171420.

135 Dean AJ, Ku BS, Zeserson EM. The utility of handheld ultrasound in an austere medical setting in Guatemala after a natural disaster. Am J Disaster Med 2007; 2: 249-256.

$136 \mathrm{Ma}$ OJ, Norvell JG, Subramanian S. Ultrasound applications in mass casualties and extreme environments. Crit Care Med 2007; 35 (5 suppl): S275-S279.

137 Shorter M, Macias DJ. Portable handheld ultrasound in austere environments: use in the Haiti disaster. Prehosp Disaster Med
2012; 27: 172-177.

138 Stawicki SP, Howard JM, Pryor JP, Bahner DP, Whitmill ML, Dean AJ. Portable ultrasonography in mass casualty incidents: the CAVEAT examination. World J Orthop 2010; 1: 10-19.

139 American College of Emergency Physicians Policy Statement: Emergency Ultrasound Guidelines. Approved October 2008. Available at www.acep.org/ultrasound. Accessed on October 22, 2013.

140 Law J, Macbeth PB. Ultrasound: from Earth to space. Mcgill J Med 2011; 13: 59.

141 Sargsyan AE, Hamilton DR, Jones JA, Melton S, Whitson PA, Kirkpatrick AW, et al. FAST at MACH 20: Clinical Ultrasound Aboard the International Space Station. J Trauma 2005; 58: 35-39.

142 Forgey W. Wilderness Medicine. Pittsboro, Indiana: Indiana Camp Supply Books, 1979.

143 Forgey WW. Wilderness Medicine, 6th edition. Guilford, Connecticut: FalconGuides, 2012.

149 Guyatt G, Gutterman D, Baumann MH, Addrizzo-Harris D, Hylek EM, Phillips B, et al. Grading strength of recommendations and quality of evidence in clinical guidelines: report from an American College of Chest Physicians Task Force. Chest 2006; 129: 174-181.

144 Davis C, Engeln A, Johnson E, McIntosh SE, Zafren K, Islas AA, et al. Wilderness Medical Society Practice Guidelines for the Prevention and Treatment of Lightning Injuries. Wilderness Environ Med 2012; 23: 260-269.

145 Drake B, Paterson R, Tabin G, Butler FK Jr, Cushing T; Wilderness Medical Society. Wilderness Medical Society Practice Guidelines for Treatment of Eye Injuries and Illness in the Wilderness. Wilderness Environ Med 2012; 23: 325-336.

146 Gaudio F, Lemery J, Johnson D. Wilderness Medical Society Roundtable Report: recommendations on the use of epinephrine in outdoor education and wilderness settings. Wilderness Environ Med 2010; 21: 185-187.

147 Winterberger E, Jacomet H, Zafren K, Ruffinen GZ, Jelk B. Wilderness \& Environmental Medicine. The Use of Extrication Devices in Crevasse Accidents: Official Statement of the International Commission for Mountain Emergency Medicine and the Terrestrial Rescue Commission of the International Commission for Alpine Rescue Intended for Physicians, Paramedics, and Mountain Rescuers. Wilderness Environ Med 2008; 19: 108-110.

148 Bennett BL, Hew-Butler T, Hoffman MD, Rogers IR, Rosner MH. Wilderness Medical Society Practice Guidelines for Treatment of Exercise-Associated Hyponatremia. Wilderness Environ Med 2013; 24: 228-240.

149 Lipman GS, Eifling KP, Ellis MA, Gaudio FG, Otten EM, Grissom CK. Wilderness Medical Society Practice Guidelines for the Prevention and Treatment of Heat-Related Illness. Wilderness Environ Med, October 16, 2013 [Epub ahead of print].

150 Warden CR, Millin MG, Hawkins SC, Bradley RN. Medical direction of wilderness and other operational emergency medical services programs. Wilderness Environ Med 2012; 23: $37-43$.

151 Bennett BL. A time has come for wilderness emergency medical service: a new direction [editorial]. Wilderness Environ Med 2012; 23: 5-6.

Received September 10, 2013 Accepted after revision January 15, 2014 